Citation: This paper appears in Sociological Forum. Please use the following citation:

Horowitz, Jonathan. 2016. "Dimensions of Job Quality, Mechanisms, and Subjective Well-Being in the United States." Sociological Forum 31:419-440. 
Dimensions of Job Quality, Mechanisms, and Subjective Well-Being in the United States Jonathan Horowitz University of North Carolina-Chapel Hill

Please direct correspondence to Jonathan Horowitz, Department of Sociology, CB \#3210, University of North Carolina, Chapel Hill, NC 27599 (jonathanhorowitzresearch@unc.edu). I am indebted to Arne Kalleberg, Jessica Pearlman, Ken Bollen, David Braudt, Kristen Schorpp, C. Shane Elliott, J. Adam Lind, Ken Hudson, and the UNC Inequality workshop for comments on an earlier version of this manuscript. 


\begin{abstract}
How does job quality predict subjective well-being in the United States? Prior research suggests that various job quality dimensions such as job security and individual task discretion affect subjective well-being, but the theoretical mechanisms are implied rather than tested and aspects of job quality are rarely tested together. I use structural equation modeling and General Social Survey data to assess the impact of five job quality dimensions-individual task discretion, monetary compensation, job security, low work intensity, and safe work conditions — on subjective well-being. Then, I show that job quality influences subjective well-being by improving social life, altering class identification, affecting physical health, and increased amount of leisure time. Finally, while I find that job quality dimensions do have statistically significant effects on subjective well-being, the way in which job quality affects subjective wellbeing differs by job dimension. In other words, job quality has a statistically significant impact on subjective well-being, but different job quality domains are connected to subjective wellbeing in different ways.
\end{abstract}

Keywords: work, job quality, subjective well-being, happiness 


\section{Dimensions of Job Quality, Mechanisms, and Subjective Well-Being in the United States}

How does job quality predict subjective well-being in the United States? American adults spend more time at work than in any other activity (Hermanowicz 2010), and the effects of work often spill over into other life domains (Settersten Jr. 2003). Thus, scholars have long suggested the importance of job quality to happiness (Green 2006; Jencks, Perman, and Rainwater 1988;

Kalleberg 2011). However, the theoretical mechanisms connecting job quality to subjective wellbeing are implied rather than tested, and there are very few studies showing how a single job quality dimension matters in the presence of other job quality characteristics. While there is a general assumption that job quality leads to greater subjective well-being, we have surprisingly little evidence to prove it.

The purpose of this study is to demonstrate the how different job quality dimensions predict subjective well-being via multiple potential mechanisms. I first estimate the effect of individual task discretion, monetary compensation, job security, low work intensity, and safe work conditions on subjective well-being. Then, I show that social life, higher class identification, better physical health, and greater leisure time mediate the relationship between various job quality dimensions and subjective well-being. As a result, the present analysis provides stronger evidence for the importance of “good job” characteristics, as each job quality dimension has a statistically significant effect on subjective well-being but is mediated by a different set of mechanisms.

\section{The Multi-Dimensional Nature of Job Quality}

What makes for a "good job”? Scholars note that experiences at work vary along a number of individual dimensions (Daw and Hardie 2012; de Bustillo, Fernández-Macías, Esteve, and Antón 2011; Jencks, Perman, and Rainwater 1988). However, analytically distinguishing 
between these dimensions can be very difficult because jobs with one good job quality (e.g., monetary compensation) are also likely to have many other good job qualities (e.g., individual task discretion). In other words, there is tendency for good and bad job qualities to "cluster" within jobs, and each good or bad job characteristic rarely appears by itself (Holman 2013; Hudson 2007; Kalleberg 2011; Vidal 2013). Scholars do not always use the same dimensions of job quality in their analyses (Vidal 2013), but most job quality scholars include some combination of the following job quality characteristics: Monetary compensation, job security, individual task discretion, work intensity, and safe working conditions. These five dimensions of job quality form the basis of the present analysis ${ }^{1}$.

The first major type of job quality is monetary compensation, most frequently measured by income or wages (Daw and Hardie 2012; Fernandez-Macias 2012; Green 2006; Handel 2005; Holman 2013; Hudson 2007; Kalleberg 2011; Kalleberg, Reskin, and Hudson 2000; OkaySomerville and Scholarios 2013; Sengupta, Edwards, and Tsai 2009; Vidal 2013). Monetary compensation is often used as a measure of job quality for two reasons. First, there is substantial evidence that income leads to greater happiness and excitement for life (Acock and Kiecolt 1989; Lee and Ono 2012; Louis and Zhao 2002; Schnittker 2008). Second, because people often choose to work because they want to earn money, the monetary compensation awarded to individuals is a measure of job quality with high face validity. In fact, some scholars actually use wages as a proxy for overall job quality (Fernandez-Macias 2012). However this exclusive focus on income is generally rejected by most scholars of work and occupations (e.g., Green 2006;

\footnotetext{
${ }^{1}$ There are two major types of job quality that are omitted in this paper. Opportunities for training and promotion is a widely accepted job quality dimension, but earlier models in this study using this approach found that an abnormally high correlation (0.721) between opportunities for training and promotion (OTP) and individual task discretion (ITD). Additionally, many scholars use intrinsic rewards as a dimension of job quality, but in comparison to the other job dimensions there is little agreement over its definition. Thus, it is not clear how to operationalize the construct or whether it is subsumed by other dimensions such as task discretion.
} 
Handel 2005; Vidal 2013), as the relationship between wages and other job quality dimensions is heterogeneous (Sengupta, Edwards, and Tsai 2009). In fact, Holman (2013) suggests that using wages or income may not necessarily capture all monetary rewards; another facet of monetary compensation is whether or not a worker receives a fixed salary (rather than one that varies with hours worked or performance). Thus, not only are wages an incomplete way to measure overall job quality, they may not even capture all aspects of monetary compensation ${ }^{2}$.

The second job quality dimension is job security, defined as the likelihood of losing one's job and the accompanying subjective feelings of perceived job insecurity that accompany it (Daw and Hardie 2012; Green 2006; Holman 2013; Hudson 2007; Kalleberg, Reskin, and Hudson 2000; Okay-Somerville and Scholarios 2013; Vidal 2013). Monetary compensation and job security are the two primary dimensions favored by dual-labor market theorists, who argue that jobs exist in either a well-paid and secure primary labor market or a poorly-paid and contingent secondary labor market (e.g., Daw and Hardie 2012; Edwards 1979; Hudson 2007). Job security consists of both objective characteristics such as the likelihood that you lost or will lose your job (e.g., Kalleberg 2011; Vidal 2013) and subjective characteristics that represent the feeling that you might lose your job (e.g., Fullerton and Wallace 2007; Handel 2005) ${ }^{3}$. However, job-related perceived insecurity is distinct from overall labor market insecurity (Kalleberg and Marsden 2012). Overall, researchers have already found a negative relationship between

\footnotetext{
${ }^{2}$ Kalleberg (2011) also includes fringe benefits as a form of monetary compensation. These include health, retirement, and sick/vacation leave. Unfortunately, the measures for these job-related characteristics are only available in for one year of the data in this study. As a result, I am unable to include them as indicators here. ${ }^{3}$ The subjective and objective components of job security forms a recurring theme in theoretical conceptions of insecurity. Kalleberg (2011) posits a single construct of "job security" which has both objective and subjective aspects. Thus, job insecurity should manifest itself in both objective and subjective ways, as two different indicators of a single dimension. Green (2005) has a similar viewpoint on the subjective and objective indicators of job security: He argues that any good measurement of job insecurity should have both objective and subjective components in the measurement, or at the minimum there should be correspondence across measures. As a result, using both objective and subjective measurements is in line with both Kalleberg's (2011) and Green's (2005) conceptualization of job security and goals.
} 
insecurity and subjective well-being, although the mechanisms remain unclear (Clark, Knabe, and Rätzel 2010; Lucas, Clark, Georgellis, and Diener 2004).

The third job quality dimension in this study is individual task discretion, and is defined as the control that a worker has over how job tasks are completed (Barnett and Brennan 1995; de Bustillo, Fernández-Macías, Esteve, and Antón 2011; Glavin 2013; Green 2006; Handel 2005; Kalleberg 2011; Okay-Somerville and Scholarios 2013; Sengupta, Edwards, and Tsai 2009). Researchers see task discretion as a highly desirable job quality because of its relationship with intrinsic rewards (Kalleberg 2011), but also because Kohn and Schooler (1983) find that occupational self-direction—a construct similar to individual task discretion—plays an important role in psychological functioning. However, while individual task discretion is an important part of job quality, it may not have a direct effect on quality of life; Vidal (2013) suggests that task discretion is part of the labor process that generates monetary compensation, work intensity, job security, and opportunities for training and promotion. Thus, Vidal (2013) implies that the effects of individual task discretion may affect quality of life indirectly via other job quality dimensions. Furthermore, there is some evidence that task discretion may not have a direct effect after considering work intensity (Rafferty, Friend, and Landsbergis 2001).

The fourth aspect of job quality is work intensity, defined as having too much work to do (Anderson-Connolly, Grunberg, Greenberg, and Moore 2002; Barnett and Brennan 1995; Grunberg, Anderson-Connolly, and Greenberg 2000), or being forced to work harder or at greater speed (Kalleberg 2011; Vidal 2013). Although not all typologies of job quality include work intensity, work intensity has been a theoretically important construct for over a century (Fairris 2004). Furthermore, work intensity is a major contemporary issue; scholars suggest that technological changes, layoffs, and changes in management style have increased work intensity 
in recent eras (Green 2006; Grunberg, Anderson-Connolly, and Greenberg 2000; Kalleberg 2011; Vidal 2013).

Finally, scholars have noted the importance of safe working conditions (de Bustillo, Fernández-Macías, Esteve, and Antón 2011), which is sometimes called "safety climate" (Hadjimanolis and Boustras 2013: 51; Smith and DeJoy 2012: 69; Zohar 1980). While not all jobs are equally safe, workplaces can create a context where safety procedures are followed and emphasized (Smith and DeJoy 2012; Zohar 1980). Unlike many other types of job quality, safe working conditions are emphasized more emphatically by public health researchers than by sociologists. However, sociologists also consider dangerous working conditions a sub-optimal job quality (Bernhardt 2012; Wahl and Gunkel 1999).

\section{Connecting Job Quality to Subjective Well-Being}

What are the mechanisms connecting job quality to subjective well-being? Generally speaking, the effect of job quality dimensions on subjective well-being is taken for granted. However, current research provides some clues that may connect each job quality dimension to well-being outcomes. While there has been evidence that everything from the perception of other people’s sex lives to the weather impacts subjective well-being (Connolly 2013; Wadsworth 2014), not all of these factors are likely influenced by job quality. Indeed, most of the factors listed by Yang (2008) are not necessarily related to job quality in an obvious way. There are also two factors—-marital quality and stress—which could mediate the effect of job quality on subjective well-being, but are not testable in the current analysis ${ }^{4}$. As a result, this study focuses

\footnotetext{
${ }^{4}$ I am unable to include marital quality because doing so would limit the analysis to married individuals only. This is a serious problem not only because it would remove a large portion of the analytic sample, but also because divorce would cause survivorship bias. Furthermore, I am unable to include stress in this study because there all of the stress measures in the analytic sample overlap with either subjective well-being or job quality.
} 
on four factors that are likely influenced by job quality dimensions and that impact on subjective well-being. These are leisure time, social life, subjective perceptions of social status, and health.

The most obvious way that job quality affects subjective well-being is that if a person spends more time at work, then they have less time to do other things that they enjoy (Newman, Tay, and Diener 2014). Employees with a greater work intensity need to work more hours in order to finish their work for the day (Burke, Singh, and Fiksenbaum 2010), and thus have fewer time to “detach” from work and recover (Fritz, Yankelevich, et al. 2010). In addition, more free time allows participants to engage in "serious leisure,” which leads to greater growth and happiness (Kim et al. 2015). Further evidence for the importance of leisure time is that the weekend plays a key restorative effect on subjective well-being (Fritz, Sonnentag, et al. 2010). Therefore, we should expect that low levels of work intensity will lead to more leisure hours, which then will increase subjective well-being.

However, poor job quality could also affect subjective well-being by making workers less likely to socialize with friends. While reductions in social life could be due to a loss of leisure time, work intensity may also lead workers to prioritize non-social leisure time activities. For example, many workers respond to job-related stress by exercising, watching television, or performing other solitary activities (Sonnentag 2001; Wu and Porell 2000). Individuals who make less money may be less able to engage in more costly social activities with friends, such as going to movies or going out to dinner. However, it is possible that individuals who engage in a great deal of self-directed activity at work may make and deepen friendships with their coworkers, clients, and business partners (Fine 1986; Price and Arnould 1999). Thus, we would expect high levels of individual task discretion, high amounts of monetary compensation, and low levels of work intensity to provide greater chances for socializing. 
While there is substantial evidence that income leads to greater levels of subjective wellbeing, the exact theoretical mechanism linking money and happiness is difficult to determine. Clark, Frijters, and Shields (2008) argue that is not the total amount of money that generates happiness, but rather whether you have more money than others around you ${ }^{5}$. Chang (2013) develops this model further by noting that changes in income change an individual's “positional identity.” Individuals who make more money often subjectively view themselves as being part of a "higher" social class, which has been associated with greater degree of happiness (Guven and Sørensen 2012; Haring, Stock, and Okun 1984). Other types of humiliations, such as a lack of workplace autonomy and high levels of work intensity could also affect an individual's subjective social class identification. As a result, certain types of workplace conditions could make individuals feel like they are "higher" or "lower” in the American class structure, leading to different levels of subjective well-being.

Finally, previous scholarship has documented the impact of job quality on health, and physical health has an effect on overall happiness ${ }^{6}$ (Yang 2008). In particular, scholars have noted that job insecurity and income impact health (Burgard, Brand, and House 2007; Burgard, Brand, and House 2009; Coverdill, López, and Petrie 2011; Cummings and Braboy Jackson 2008; Fullerton and Anderson 2013; Sparks et al 1997). Furthermore, high work intensity often leads to sub-optimal health (Anderson-Connolly, Grunberg, Greenberg, and Moore 2002; Fujishiro, Xu, and Gong 2010), although this is sometimes mitigated by high levels of individual task discretion. Furthermore, poor safety climate can lead to both injury and illness (Smith and

\footnotetext{
${ }^{5}$ Note that this effect could vary by the amount of happiness someone already has (Boes and Winkelmann 2004), which increases the importance of including multiple competing reasons why job quality could impact happiness.

${ }^{6}$ While it is theoretically plausible that someone who is very unhappy could also suffer negative health consequences, this is not how researchers operationalize this relationship (Papavlassopulos and Keppler 2011; Yang 2008). This is because it is much more likely that a high level of stress would cause both health problems and unhappiness; for more information, see (Turner 2013) for a succinct summary of the stress process model.
} 
DeJoy 2012). Thus, it seems likely physical health mediates the impact of job insecurity, work intensity, and safe working conditions on subjective well-being.

In summary, previous scholarship has documented that show that monetary compensation, job security, and individual task discretion impact subjective well-being; but empirical mechanisms are rarely proposed and tested, and very few studies account for the presence of multiple job quality dimensions. Thus, the present study (a) tests for the relationship between multiple job quality dimensions and subjective well-being, and then (b) investigates whether leisure time, the frequency of social activities, subjective class identification, and physical health mediate these relationships.

\section{Data and Methods}

In this study, I use data from the General Social Survey (GSS) and structural equation modeling to test relationships between job quality and subjective well-being. The GSS is a nationally representative sample of adults in the United States that asks a large number of questions about experiences at work (Smith, Marsden, Hout, and Kim 2010). In particular, the General Social Survey introduced a new battery of questions titled “Quality of Working Life” in 2002 (and repeated in 2006 and 2010) which includes multiple questions about several job quality dimensions. The job quality dimensions that I use, observed indicators from the General Social Survey, and information about whether I reversed and/or transformed the variable are all listed in Table $1^{7}$. Overall, I use fourteen different job quality indicators that measure five separate job quality dimensions, from 2002, 2006, and 2010.

\section{TABLE 1 ABOUT HERE}

\footnotetext{
${ }^{7}$ I reverse the coding of most of the ordinal indicators for ease of interpretation; in this study, better outcomes are assigned to higher values.
} 
To test whether each job quality indicator actually represents a job quality characteristic, I estimate a structural equation model (SEM) which represents each job quality dimension as a latent variable (Bollen 1989). This helps to remove measurement error associated with survey items, which is a major benefit given that job quality characteristics tend to cluster together and items could therefore potentially represent more than one job quality dimension. The full list of indicators and latent variables may be found in Table 1; for example, the latent variable "Not Intense” is represented by the indicators "Work Time,” “Overwork,” and “Too Few Workers.” This type of SEM-sometimes called a "measurement model”- is equivalent to confirmatory factor analysis, and represents each job quality dimension as a latent variable. The coefficient between the latent variable and the observed indicators show how each observed indicator measures the latent variable.

I use several overall fit statistics to assess the plausibility the first measurement model. When the Tucker-Lewis Index (TLI) and Confirmatory Fit Index (CFI) are closer to 1, the model provides evidence in favor of the hypothesized model structure. In general, the TLI and CFI are considered "adequate” when they are above 0.90, and "good” when they are above 0.95 (Bentler 1990; Tucker and Lewis 1973). In contrast, the Root-Mean Square Error of Approximation (RMSEA) provides evidence for the hypothesized model when it is close to zero; an RMSEA below 0.1 is considered “adequate,” and an RMSEA below 0.05 is considered "good” (Browne and Cudeck 1992).

There are two likely scenarios where a measurement model would fit poorly. First, a model will have poor fit if any set of grouped indicators (e.g., "Work Freedom” and "Lot of Say at Work) are not caused by the same latent factor. Second, the model will fit badly if a single indicator (e.g., "Work Freedom”) is actually the result of two separate latent variables (e.g., 
“Individual Task Discretion” and "Monetary Compensation”). Models with good overall fit suggest that the indicators are visible manifestations of the proposed underlying latent variable. In this case, the model fit statistics are extremely good; the TLI is 0.989, the CFI is 0.992, and the RMSEA is 0.036. Thus, the five-factor model of job quality is consistent with the data, and it is likely that the proposed indicators represent the corresponding latent variables.

\section{TABLE 2 ABOUT HERE}

In addition, the General Social Survey also includes several indicators that represent subjective well-being, as well as data on social activities, subjective class identification, hours available for leisure activities, and physical health. The variables for subjective well-being and the mediators, along with the recoded responses, are listed in Table 2. The two indicators for subjective well-being are happiness and excitement for life, which are frequently used both separately and combined as a measure of general well-being (Acock and Kiecolt 1989; Coverdill, López, and Petrie 2011; Hughes and Thomas 1998; Louis and Zhao 2002; Taylor and Schroeder 2010; Thomas and Hughes 1986). I then estimate a measurement model that includes all five job quality dimensions, social life, and subjective well-being in the same model. The fit statistics for this model are extremely good (TLI=0.990; CFI=0.993; RMSEA=0.023). The factor loadings and fit statistics for both confirmatory factor analyses can be found in Appendix A.

I then estimate two structural equation models to test the impact of each job quality dimension on subjective well-being. The first model (Model 1, shown in Figure 1) looks at the effect of job quality on subjective well-being, but does not include any control or mediating variables. The interpretation of the coefficients is similar to standard regression approaches. For example, the coefficient representing the impact of job security on subjective well-being (the arrow pointing from JS to SWB) represents the one-unit change of job security on subjective 
well-being, net of the other domains of job quality. Statistically significant relationships provide evidence for a relationship between the predictor and outcome variable in the population, while non-significant relationships suggest that effect sizes may be due to sampling error instead of a true, population-level relationship.

\section{FIGURE 1 ABOUT HERE}

The second model (Model 2, shown in Figure 2) examines whether the impact of job quality on subjective well-being holds after accounting for potential confounding relationships. Based on previous studies investigating subjective well-being, personal characteristics such as racial/ethnic background, sex, age, educational attainment, marital status, having children, and religious service attendance have far-reaching impacts on individual outcomes (Acock and Kiecolt 1989; Coverdill, López, and Petrie 2011; Hughes and Thomas 1998; Louis and Zhao 2002; Taylor and Schroeder 2010; Thomas and Hughes 1986). In addition, I also include survey year to account for potential period effects that could impact both job quality and subjective well-being (Yang 2008).

FIGURE 2 ABOUT HERE

Finally, Model 3 (in Figure 3) examines the mechanisms for job quality’s effects on subjective well-being. Prior scholarship suggests that individual task discretion, monetary compensation, and work intensity could impact a worker’s social life; that monetary compensation, job security, work intensity, and safe work conditions affect physical health; that individual task discretion, monetary compensation, and work intensity could alter subjective class identification; and that work intensity affects an individual's amount of leisure time. I also estimate the direct effect of job quality on subjective well-being to determine whether the present 
mediators account for the entire effect of job quality on subjective well-being, or whether there are other unaccounted mediators.

Ultimately, the present research shows the effect of individual job quality characteristics on subjective well-being after taking into account other aspects of job quality, other factors, and mechanisms of action. Furthermore, this study addresses measurement error in observed variables by estimating latent variables. One of the limitations of this study is that it is difficult to prove causal relationships with cross-sectional data; however, addressing explanations due to omitted variable bias, identifying the mechanisms linking job quality to subjective well-being, and removing measurement error provides a stronger test of job quality’s impact on subjective well-being than demonstrated in previous research.

\section{FIGURE 3 ABOUT HERE}

In this study, I model the impact of five different dimensions of job quality on subjective well-being, and test for whether this effect is mediated by social life, class identification, physical health, and hours available for leisure activities; the level of measurement and descriptive statistics for each indicator are listed in Table 3. Because observed indicator variables are categorical, I estimate all models using Weighted Least Squares-Mean/Variance (WLS-MV) in MPlus, which is the most effective way to handle missing data for ordinal and dichotomous indicators (Asparouhov and Muthén 2010). I declare all ordinal and dichotomous indicators of latent variables as categorical; the remaining variables are treated as a continuous.

\section{TABLE 3 ABOUT HERE}

\section{Findings}

In this section, I present the effects of job quality on subjective well-being. Fit statistics for each model are listed in Appendix A, but I report the effects of job quality, the mediators, and 
the additional covariates on subjective well-being in Table 4. I organize the findings by dependent variable, so that all of coefficients predicting subjective well-being come first, followed by the predictors of each mediator.

In the first model, I estimate the effect of job quality on subjective well-being without any additional covariates or mediators. Each coefficient has an interpretation that is comparable to standard regression equations - the impact of each job quality dimension on subjective wellbeing, net of the other job quality domains. For example, monetary compensation $(\mathrm{p}<0.001)$ has a statistically significant impact on subjective well-being, after accounting for variation associated with the other four job dimension categories. Job security $(\mathrm{p}<0.001)$, low work intensity $(\mathrm{p}<0.001)$, safe working conditions $(\mathrm{p}<0.001)$, and individual task discretion $(\mathrm{p}<0.01)$ also have a statistically significant impact on subjective well-being. The findings that monetary compensation and job security have an effect on subjective well-being are consistent with prior research (Acock and Kiecolt 1989; Lee and Ono 2012; Louis and Zhao 2002; Schnittker 2008). However, Model 1 also finds effects for low-intensity work environments, individual task discretion, and safe working conditions.

\section{TABLE 4 ABOUT HERE}

In Table 5, I present standardized coefficients in order to assess which job quality characteristic has the greatest effect on subjective well-being. Without any additional covariates in in the model, the largest effect sizes are monetary compensation $(\beta=.235)$ and job security ( $\beta=.201)$. However, individual task discretion $(\beta=.139)$, low work intensity $(\beta=.150)$, and safe work conditions ( $\beta=.131$ ) each have a substantial effect on subjective well-being, although each effect size is roughly two-thirds that of monetary compensation and job security.

\section{TABLE 5 ABOUT HERE}


Model 2 tests the impact of job quality on subjective well-being, after accounting for other potentially confounding relationships. Most of the relationships are unaffected by the introduction of the additional covariates; individual task discretion $(\mathrm{p}<0.05)$, low-intensity work environments $(\mathrm{p}<0.001)$, job security $(\mathrm{p}<0.001)$, and safe work conditions $(\mathrm{p}<0.001)$ have approximately the same effect sizes on subjective well-being as in Model 1. For example, in Model 1 having a low-intensity work environment has an effect of $\beta=.117$ on subjective wellbeing, and with the additional covariates added the effect barely changes ( $\beta=.119)$. However, the effect of monetary compensation $(\mathrm{p}<0.01)$ declines from 0.234 to 0.178 , suggesting that some of the effect of monetary compensation on subjective well-being is spurious. The decline of substantive significance of monetary compensation in Model 2 is also visible when comparing the standardized coefficients to each other. In Model 1, monetary compensation and job security had much stronger effects on subjective well-being than the other job quality characteristics. After introducing additional covariates, all five job quality characteristics have similar effect sizes to each other; individual task discretion $(\beta=.129)$, monetary compensation $(\beta=.127)$, job security $(\beta=.149)$, low-intensity work environments $(\beta=.134)$, and safe working conditions $(\beta=.110)$.

Finally, Model 3 tests how different mechanisms account for the relationship between job quality and subjective well-being. First, social life $(\mathrm{p}<0.001)$, class identification $(\mathrm{p}<0.001)$, physical health $(\mathrm{p}<0.001)$, and hours available for relaxation $(\mathrm{p}<0.01)$ all have a statistically significant effect on subjective well-being. The effect of individual task discretion on subjective well-being is completely mediated by social life $(\mathrm{p}<0.001)$ and by class identification $(\mathrm{p}<0.001)$. Furthermore, the effect of monetary compensation on subjective well-being drops from $\beta=.168$ to $\beta=.126$; this is because it is mediated by class identification $(\mathrm{p}<0.001)$ and physical health 
( $\mathrm{p}<0.001$ ), but not by an individual's social life. Meanwhile, low work intensity has a direct effect on subjective well-being $(\mathrm{p}<0.001)$ and also has an indirect effect via increased leisure time ( $<<0.001)$, but no direct effects via social life.

Two job quality characteristics have strong direct effects on subjective well-being, but no indirect effects. Safe working conditions $(\mathrm{p}<0.01)$ and job security $(\mathrm{p}<0.001)$ have strong direct effects on subjective well-being but no indirect effects via physical health ${ }^{8}$. For both safe working conditions and job security, the unstandardized coefficients barely change between Models 2 and 3, further demonstrating that physical health does not mediate either characteristic. Overall, the standardized coefficients show that the job security has the strongest unmediated effect on subjective well-being of all job quality characteristics ( $\beta=.145)$; meanwhile, monetary compensation ( $\beta=.097)$, low-intensity work environments $(\beta=.095)$, and safe working conditions ( $\beta=.106)$ have approximately the same direct effect on subjective well-being.

\section{TABLE 6 ABOUT HERE}

Table 6 lists a summary of the results, showing how job quality affects subjective wellbeing. In summary, job quality does affect subjective well-being, but different types of job quality affect subjective well-being in different ways. After accounting for potentially confounding relationships, individual task discretion and monetary compensation have no direct effects on subjective well-being, but they do have indirect effects via class identification, physical health, and social life. Meanwhile low-intensity work conditions affect subjective wellbeing directly, but also via physical health and class identification. Finally, job security and safe

\footnotetext{
${ }^{8}$ This is likely because the items tapping safe work conditions have a relationship with physical safety in some occupations rather than others. For example, an unsafe construction site likely does not follow safety protocols and puts workers at physical risk, and should lead to poor days of physical health. Meanwhile, the stakes for physical injury are often much lower in an unsafe office environment. Therefore, future research should investigate whether this relationship differs by subgroup.
} 
working conditions have only direct effects on subjective well-being, with none of the effect mediated by physical health.

I also estimate the indirect effects (with standardized coefficients) for each pathway in Table 7, which helps to demonstrate that some indirect effects are stronger than others. For example, individual task discretion operates primarily by increasing social life $(\beta=.046)$ rather than subjective class identification $(\beta=.013)$. Meanwhile, monetary compensation increases subjective well-being more via subjective class identification $(\beta=.030)$ instead of physical health $(\beta=.011)$. Finally, having low-work intensity has some effects via both physical health $(\beta=.011)$ and having hours to relax $(\beta=.013)$, both of which are much larger effects than via subjective class identification $(\beta=.006)$. This further demonstrates that although job quality characteristics are highly inter-correlated and all lead to greater subjective well-being, the actual effects of job quality characteristics are unique.

\section{TABLE 7 ABOUT HERE}

\section{Discussion}

Prior to this study, scholars have generally assumed that job quality increases subjective well-being, but the evidence for some dimensions (e.g., job security) has been much greater than for others (e.g., low work intensity). Furthermore, previous research tended to examine only one job quality characteristic at a time, and thus a statistically significant relationship could be due to omitted variable bias. I demonstrate the effect of several dimensions of job quality in two different ways: First, I show that different job quality dimensions have statistically significant effects in the presence of other job quality characteristics. This study confirms the effects of job security (Acock and Kiecolt 1989; Lee and Ono 2012; Louis and Zhao 2002; Schnittker 2008), monetary compensation (Clark, Knabe, and Rätzel 2010; Lucas, Clark, Georgellis, and Diener 
2004), and task discretion (Kohn and Schooler 1983) on subjective well-being. Furthermore, the present study also shows that low intensity and safe work conditions can also increase subjective well-being. As a result, the study shows that each of these has a statistically significant effect on subjective well-being, even in the presence of the others.

Second, I show that each job quality dimension affects subjective well-being through different mechanisms. These establish that different dimensions of job quality have their own, unique effects on subjective well-being. Some job quality dimensions are completely mediated by social life, physical health, class identification, and time to relax, while two job quality domains (job security and safe work conditions) are not mediated at all. Furthermore, job quality domains rarely have the same pattern as another, suggesting that while job quality characteristics may cluster together (Green 2006; Kalleberg 2011), job quality characteristics have a unique effect on a worker's happiness. By testing several theoretical mechanisms, this study strengthens the case that job quality has an impact on a worker's subjective well-being.

Theoretically, the fact that all five job quality characteristics matter-but don’t necessarily matter in the same way-has two additional implications for future research. First, some scholars have proposed using a single job quality dimension as a stand-in for job quality (e.g., Fernandez-Macias 2012); since all job quality dimensions are inter-correlated with each other, this appears to be an appropriate analysis technique. However, each of the job quality characteristics are related to subjective well-being in a different way, suggesting that job quality characteristics do not have uniform effects on distal outcomes. For example, monetary compensation affects physical health and subjective class status, but not social life; if the theoretical model assumes that job quality increases the quality of a participants' social life, then it is inappropriate to use monetary compensation as a stand-in for job quality. As a result, 
scholars should, whenever possible, use multiple job quality characteristics to account for different explanatory mechanisms.

Second, scholars using regression methods often introduce additional covariates to “control” for potentially spurious factors. These additional covariates are usually demographic variables (e.g., sex, race) that are causally prior to both occupational standing and more distal outcomes. However, sometimes scholars introduce variables such as social relationships, leisure time, or physical health to help account for other potentially spurious relationships. That said, the present analysis suggests that several of these covariates mediate the relationship between job quality and subjective well-being, and are not spurious effects. Therefore, including these types of covariates in the model will understate total effect of job quality on outcomes by eliminating indirect effects.

There are two major ways in which future studies could build upon these results. First, this study looks at the impact of job quality in a cross-sectional manner. At a practical level, inferring causal relationships via cross-sectional surveys is more difficult than using panel data. The present study uses cross-sectional data because the General Social Survey includes a large battery of questions about job quality, subjective well-being, and potential mediators, and there is some evidence that cross-sectional studies of job quality return similar findings as longitudinal designs (Nixon et al. 2011). Furthermore, this study does include several methodological tools to address measurement error, omitted variable bias, and to identify potential mechanisms; these provide a stronger test of the relationship between job quality and subjective well-being than prior research has demonstrated. However, future studies should replicate these findings with panel data to confirm the present analyses. 
However, there is also a good theoretical reason to look at job quality over time: There is substantial evidence that job experiences early in life can affect individuals many years later (e.g., Elder 1999; Finch, Shanahan, Mortimer, and Ryu 1991). This study investigated the effects of job quality on present well-being, but in what ways does job quality affect future well-being? Furthermore, there is the question of how workers respond to good and bad job qualities: Are there particular job qualities that influence workers to leave jobs, return to school, or even to switch occupations? The present cross-sectional data limits the ability to measure how job quality matters over the life course, but this should be an area for future research.

Additionally, future scholarship should investigate how combinations of job qualities affect subjective well-being. There is already some research in this area; for example, scholars have investigated the combination of high work intensity with low individual task discretion (e.g., Fujishiro, Xu, and Gong 2010). Some scholars have also looked at the demands-resources model of job quality, which often looks at the importance of task discretion in the context of work intensity and some other, less-commonly studied job quality characteristics (Glavin and Schieman 2012; Schieman 2013). It is possible that some bad job qualities are only problematic in the presence of other job qualities; for example, high work intensity may not have deleterious effects in the presence of high job security. However, analyzing combinations of job qualities may be a technically challenging task. As Cummings and Braboy Jackson (2008) note, interaction terms can substantially increase multicollinearity, and job quality characteristics already tend to “cluster” together. Additionally, including other measures of job qualityincluding indicators like fringe benefits, and domains such as schedule control—would be ideal, although difficult due to high levels of multicollinearity. 
Finally, this study showed how individual task discretion and monetary compensation affect subjective well-being by affecting social life, physical health, and class identification. However, there are still substantial direct effects of job security, work intensity, and safe working conditions on subjective well-being. Furthermore, there is not substantial evidence that either job security or safe working conditions increase subjective well-being via physical health; this runs counter to existing predictions (Burgard, Brand, and House 2007; Burgard, Brand, and House 2009; Coverdill, López, and Petrie 2011; Cummings and Braboy Jackson 2008; Fullerton and Anderson 2013). In the case of safe working conditions, it is likely that a safe working environment directly leads to poor physical health in some occupations but not others; an unsafe office environment may be less likely to cause physical injury than an unsafe construction site.

Meanwhile, the remaining direct effects for job security, work intensity, and safe working conditions suggest that we do not yet fully understand why they affect subjective well-being. However, these three job quality dimensions have one major characteristic in common: They all directly increase stress (Barnett and Brennan 1995; Larson, Wilson, and Beley 1994; Perrewe and Ganster 1989), which in turn has a negative effect on subjective well-being (Suh, Diener, and Fujita 1996). Unfortunately, the General Social Survey does not have adequate measures of stress for this purpose, as many of them are confounded either with job quality dimensions or with subjective well-being. Future studies should test to see whether stress mediates the effects of job security, work intensity, and safety climate on subjective well-being.

This study also has two practical implications for organizational leaders. First, organizations that focus on monetary compensation to the detriment of other job quality characteristics may have workers with poor subjective well-being. For example, monetary compensation may lead to better subjective well-being via physical health, but if those same 
workers have high levels of work intensity it will decrease subjective well-being by damaging physical health. Second, organizations may accidentally undercut the benefits of job quality by preventing mechanisms from taking place. For example, a workplace that provides a great deal of individual task discretion but inhibits social life is accidentally preventing the full benefits of individual task discretion. Similarly, a low-work intensity environment that does not enable workers to “detach” over non-working hours may also not be as effective in developing happy workers (Fritz, Yankelevich, et al. 2010).

In summary, Americans spend more of their adult lives at work than any other non-sleep activity (Hermanowicz 2010), and thus participation in work often has dramatic effects on other life domains (Settersten Jr. 2003). The study of job quality is not new, and has intensified in recent years (Green 2006; Jencks, Perman, and Rainwater 1988; Kalleberg 2011). However, prior studies have only assessed the impact of one or two job quality dimensions on subjective well-being. The present multi-dimensional approach looks at the effects of job quality on subjective well-being while accounting for other job quality dimensions and testing for mediating effects. The results suggest that job quality has a statistically significant impact on subjective well-being, but that different job quality domains make workers happy in different ways. 


\section{References}

Acock, Alan C. and K. Jill Kiecolt. 1989. "Is It Family Structure or Socioeconomic Status?

Family Structure during Adolescence and Adult Adjustment." Social Forces 68:553-571.

Anderson-Connolly, Richard, Leon Grunberg, Edward S. Greenberg, and Sarah Moore. 2002. "Is lean mean? workplace transformation and employee well-being." Work Employment and Society 16:389-413.

Asparouhov, Timor and Bengt Muthén. 2010. "Weighted least squares estimation with missing data." Muthén \& Muthén, Los Angeles, CA.

Barkan, Steven E. and Susan F. Greenwood. 2003. "Religious attendance and subjective wellbeing among older Americans: Evidence from the General Social Survey." Review of Religious Research 45:116-129.

Barnett, Rosalind C and Robert T Brennan. 1995. "The relationship between job experiences and psychological distress: A structural equation approach." Journal of Organizational Behavior 16:259-276.

Bentler, P. M. 1990. "Comparative fit indexes in structural models." Psychological Bulletin 107:238-246.

Bernhardt, Annette. 2012. "The Role of Labor Market Regulation in Rebuilding Economic Opportunity in the United States." Work and Occupations 39:354-375.

Boes, Stefan, and Rainer Winkelmann. 2004. Income and happiness: New results from generalized threshold and sequential models. Socioeconomic Institute, University of Zurich, No. 0407.

Bollen, Kenneth A. 1989. Structural equation models. New York: John Wiley \& Sons. 
Browne, Michael W and Robert Cudeck. 1992. "Alternative ways of assessing model fit." Sociological Methods \& Research 21:230-258.

Burgard, Sarah A., Jennie E. Brand, and James S. House. 2007. "Toward a better estimation of the effect of job loss on health." Journal of Health and Social Behavior 48:369-384.

—. 2009. "Perceived job insecurity and worker health in the United States." Social Science \& Medicine 69:777-785.

Burke, Ronald J., Parbudyal Singh, and Lisa Fiksenbaum. 2010. "Work intensity: potential antecedents and consequences." Personnel Review 39:347-360.

Chang, Wen-Chun. 2013. "Climbing up the Social Ladders: Identity, Relative Income, and Subjective Well-being." Social Indicators Research 113:513-535.

Clark, Andrew E., Paul Frijters, and Michael A. Shields. 2008. "Relative Income, Happiness, and Utility: An Explanation for the Easterlin Paradox and Other Puzzles." Journal of Economic Literature 46:95-144.

Clark, Andrew, Andreas Knabe, and Steffen Rätzel. 2010. "Boon or bane? Others' unemployment, well-being and job insecurity." Labour Economics 17:52-61.

Connolly, Marie. 2013. "Some like it mild and not too wet: The influence of weather on subjective well-being." Journal of Happiness Studies no. 14 (2):457-473.

Coverdill, James E., Carlos A. López, and Michelle A. Petrie. 2011. "Race, Ethnicity and the Quality of Life in America, 1972-2008." Social Forces 89:783-805.

Cummings, Jason L. and Pamela Braboy Jackson. 2008. "Race, gender, and SES disparities in self-assessed health, 1974-2004." Research on Aging 30:137-167.

Daw, Jonathan and Jessica Halliday Hardie. 2012. "Compensating differentials, labor market segmentation, and wage inequality." Social Science Research 41:1179-1197. 
de Bustillo, Rafael Muñoz, Enrique Fernández-Macías, Fernando Esteve, and José-Ignacio Antón. 2011. "E pluribus unum? A critical survey of job quality indicators." SocioEconomic Review 9:447-475.

Elder, Glen H. 1999. Children of the Great Depression : social change in life experience. Boulder, CO: Westview Press.

Fairris, David. 2004. "Towards a theory of workplace intensity." Eastern Economic Journal 30:587.

Fernandez-Macias, Enrique. 2012. "Job Polarization in Europe? Changes in the Employment Structure and Job Quality, 1995-2007." Work and Occupations 39:157-182.

Finch, Michael D., Michael J. Shanahan, Jeylan T. Mortimer, and Seongryeol Ryu. 1991. "Work Experience and Control Orientation in Adolescence." American Sociological Review 56:597-611.

Fine, Gary Alan. 1986. "Friendships in the work place." Pp. 185-206 in Friendship and social interaction. New York, NY: Springer.

Fritz, Charlotte, Sabine Sonnentag, Paul E. Spector, and Jennifer A. McInroe. 2010. "The weekend matters: Relationships between stress recovery and affective experiences." Journal of Organizational Behavior 31:1137-1162.

Fritz, Charlotte, Maya Yankelevich, Anna Zarubin, and Patricia Barger. 2010. "Happy, healthy, and productive: The role of detachment from work during nonwork time." Journal of Applied Psychology 95:977-983.

Fujishiro, Kaori, Jun Xu, and Fang Gong. 2010. "What does "occupation" represent as an indicator of socioeconomic status?: Exploring occupational prestige and health." Social Science \& Medicine 71:2100-2107. 
Fullerton, Andrew S and Michael Wallace. 2007. "Traversing the flexible turn: US workers’ perceptions of job security, 1977-2002." Social Science Research 36:201-221.

Fullerton, Andrew S. and Kathryn Freeman Anderson. 2013. "The role of job insecurity in explanations of racial health inequalities." Sociological Forum 28:308-325.

Glavin, Paul. 2013. "The Impact of Job Insecurity and Job Degradation on the Sense of Personal Control." Work and Occupations 40:115-142.

Glavin, Paul, and Scott Schieman. 2012. "Work-Family Role Blurring and Work-Family Conflict: The Moderating Influence of Job Resources and Job Demands." Work and Occupations no. 39 (1):71-98. doi: 10.1177/0730888411406295.

Green, Francis. 2006. Demanding work: The paradox of job quality in the affluent economy: Princeton University Press.

Grunberg, Leon, Richard Anderson-Connolly, and Edward S. Greenberg. 2000. "Surviving Layoffs: The Effects on Organizational Commitment and Job Performance." Work and Occupations 27:7-31.

Guven, Cahit and Bent E. Sørensen. 2012. "Subjective Well-Being: Keeping Up with the Perception of the Joneses." Social Indicators Research 109:439-469.

Hadjimanolis, Athanasios and Georgios Boustras. 2013. "Health and safety policies and work attitudes in Cypriot companies." Safety Science 52:50-56.

Handel, Michael J. 2005. "Trends in perceived job quality, 1989 to 1998." Work and Occupations 32:66-94.

Haring, Marilyn J., William A. Stock, and Morris A. Okun. 1984. "A Research Synthesis of Gender and Social Class as Correlates of Subjective Well-Being." Human Relations $37: 645-657$. 
Hermanowicz, Joseph C. 2010. Lives in science: How institutions affect academic careers. Chicago, IL: University of Chicago Press.

Holman, David. 2013. "Job types and job quality in Europe." Human Relations 66:475-502.

Hudson, Kenneth. 2007. "The new labor market segmentation: Labor market dualism in the new economy." Social Science Research 36:286-312.

Hughes, Michael and Melvin E. Thomas. 1998. "The continuing significance of race revisited: A study of race, class, and quality of life in America, 1972 to 1996." American Sociological Review 63:785-795.

Jencks, Christopher, Lauri Perman, and Lee Rainwater. 1988. "What is a good job? A new measure of labor-market success." American Journal of Sociology:1322-1357.

Kalleberg, Arne L. 2011. Good jobs, bad jobs: The rise of polarized and precarious employment systems in the United States, 1970s-2000s: Russell Sage Foundation.

Kalleberg, Arne L. and Peter V. Marsden. 2012. "Labor Force Insecurity and US Work Attitudes, 1970s-2006." Social Trends in American Life: Findings from the General Social Survey Since 1972:315.

Kalleberg, Arne L., Barbara F. Reskin, and Ken Hudson. 2000. "Bad jobs in America: Standard and nonstandard employment relations and job quality in the United States." American Sociological Review:256-278.

Kim, Junhyoung, Jinmoo Heo, In Heok Lee, and Jun Kim. 2015. "Predicting personal growth and happiness by using serious leisure model." Social Indicators Research no. 122 (1):147-157.

Kohn, Melvin L and Carmi Schooler. 1983. Work and personality: An inquiry into the impact of social stratification: Ablex Norwood, NJ. 
Larson, Jeffry H., Stephan M. Wilson, and Rochelle Beley. 1994. "The Impact of Job Insecurity on Marital and Family Relationships." Family Relations 43:138-143.

Lee, Kristen Schultz and Hiroshi Ono. 2012. "Marriage, Cohabitation, and Happiness: A CrossNational Analysis of 27 Countries." Journal of Marriage and Family 74:953-972.

Louis, Vincent V. and Shanyang Zhao. 2002. "Effects of Family Structure, Family SES, and Adulthood Experiences on Life Satisfaction." Journal of Family Issues 23:986-1005.

Lucas, Richard E., Andrew E. Clark, Yannis Georgellis, and Ed Diener. 2004. "Unemployment Alters the Set Point for Life Satisfaction." Psychological Science 15:8-13.

Newman, David B., Louis Tay, and Ed Diener. 2014. "Leisure and Subjective Well-Being: A Model of Psychological Mechanisms as Mediating Factors." Journal of Happiness Studies 15:555-578.

Nixon, Ashley E., Joseph J. Mazzola, Jeremy Bauer, Jeremy R. Krueger, and Paul E. Spector. 2011. "Can work make you sick? A meta-analysis of the relationships between job stressors and physical symptoms." Work \& Stress 25:1-22.

Okay-Somerville, B. and D. Scholarios. 2013. "Shades of grey: Understanding job quality in emerging graduate occupations." Human Relations 66:555-585.

Perrewe, Pamela L. and Daniel C. Ganster. 1989. "The Impact of Job Demands and Behavioral Control on Experienced Job Stress." Journal of Organizational Behavior 10:213-229.

Price, Linda L. and Eric J. Arnould. 1999. "Commercial Friendships: Service Provider-Client Relationships in Context." Journal of Marketing 63:38-56.

Papavlassopulos, Nikolas, and David Keppler. 2011. "Life Expectancy as an Objective Factor of a Subjective Well-Being." Social Indicators Research no. 104 (3):475-505. doi: 10.1007/s11205-010-9757-6. 
Rafferty, Yvonne, Ronald Friend, and Paul A. Landsbergis. 2001. "The association between job skill discretion, decision authority and burnout." Work \& Stress 15:73-85.

Schieman, Scott. 2013. "Job-related resources and the pressures of working life." Social Science Research no. 42 (2):271-282. doi: http://dx.doi.org/10.1016/j.ssresearch.2012.10.003.

Schnittker, Jason. 2008. "Diagnosing our national disease: Trends in income and happiness, 1973 to 2004." Social Psychology Quarterly 71:257-280.

Sengupta, Sukanya, Paul K. Edwards, and Chin-Ju Tsai. 2009. "The Good, the Bad, and the Ordinary Work Identities in "Good" and "Bad" Jobs in the United Kingdom." Work and Occupations 36:26-55.

Settersten Jr., Richard A. 2003. "Propositions and controversies in life-course scholarship." Pp. 15-45 in Invitation to the life course: Toward new understandings of later life, edited by R. A. Settersten Jr. Amityville, NY: Baywood.

Smith, Todd D. and David M. DeJoy. 2012. "Occupational injury in America: An analysis of risk factors using data from the General Social Survey (GSS)." Journal of Safety Research 43:67-74.

Smith, Tom W., Peter V. Marsden, Michael Hout, and Jibum Kim. 2010. "General Social Surveys, 1972-2010: Cumulative Codebook." National Opinion Research Center, Chicago.

Sonnentag, Sabine. 2001. "Work, recovery activities, and individual well-being: A diary study." Journal of Occupational Health Psychology 6:196-210.

Suh, Eunkook, Ed Diener, and Frank Fujita. 1996. "Events and subjective well-being: only recent events matter." Journal of personality and social psychology no. 70 (5):1091. 
Taylor, Marylee C. and Matthew B. Schroeder. 2010. "The impact of Hispanic population growth on the outlook of African Americans." Social Science Research 39:491-505.

Thomas, Melvin E. and Michael Hughes. 1986. "The continuing significance of race: A study of race, class, and quality of life in America, 1972-1985." American Sociological Review 51:830-841.

Tucker, Ledyard R and Charles Lewis. 1973. "A reliability coefficient for maximum likelihood factor analysis." Psychometrika 38:1-10.

Turner, R. Jay. 2013. "Understanding Health Disparities: The Relevance of the Stress Process Model." Society and Mental Health no. 3 (3):170-186. doi: 10.1177/2156869313488121.

Vidal, Matt. 2013. "Low-autonomy work and bad jobs in postfordist capitalism." Human Relations 66:587-612.

Wadsworth, Tim. 2014. "Sex and the Pursuit of Happiness: How Other People’s Sex Lives are Related to our Sense of Well-Being." Social Indicators Research no. 116 (1):115-135. doi: 10.1007/s11205-013-0267-1.

Wahl, Ana-Maria and Steven E. Gunkel. 1999. "Due Process, Resource Mobilization, and the Occupational Safety and Health Administration, 1971-1996: The Politics of Social Regulation in Historical Perspective." Social Problems 46:591-616.

Wu, Bei and Frank Porell. 2000. "Job Characteristics and Leisure Physical Activity." Journal of Aging and Health 12:538-559.

Yang, Yang. 2008. "Social inequalities in happiness in the United States, 1972 to 2004: An ageperiod-cohort analysis." American Sociological Review 73:204-226.

Zohar, Dov. 1980. "Safety climate in industrial organizations: Theoretical and applied implications." Journal of Applied Psychology 65:96-102. 


\section{Appendix A}

In Appendix A, I present (1) the factor loadings for the confirmatory factor analysis of job quality dimensions, (2) the fit statistics for each of the structural equation models.

In Table A1, I present the factor loadings for each job quality dimension, and then for all latent variables together. All factor loadings are statistically significant at $p<0.001$.

Table A1. Confirmatory Factor Analysis of Job Quality Dimensions

\begin{tabular}{|c|c|c|c|}
\hline Latent Variable & Indicator & Job Quality Model Only & All Latent Variables \\
\hline \multirow[t]{4}{*}{ Individual Task Discretion } & Work Freedom & $1^{\circ}$ & $1^{\circ}$ \\
\hline & & $(0)$ & $(0)$ \\
\hline & Lot of Say at Work & $1.001^{\star \star \star}$ & $1.007^{\star \star \star}$ \\
\hline & & $(.042)$ & $(.042)$ \\
\hline \multirow[t]{4}{*}{ Monetary Compensation } & Logged Income & $1^{\circ}$ & $1^{\circ}$ \\
\hline & & $(0)$ & $(0)$ \\
\hline & Salary & $.946^{\star \star \star}$ & $.948^{\star \star \star}$ \\
\hline & & $(.063)$ & $(.060)$ \\
\hline \multirow[t]{6}{*}{ Job Security } & Job Security Okay & $1^{\circ}$ & $1^{\circ}$ \\
\hline & & $(0)$ & $(0)$ \\
\hline & Lose Job in Next 12 Months & $.745^{\star \star *}$ & $.763^{\star \star *}$ \\
\hline & & $(.054)$ & $(.051)$ \\
\hline & Lost Job in Last 12 Months & $.491^{\star \star \star}$ & $.499 * \star \star$ \\
\hline & & $(.044)$ & $(.043)$ \\
\hline \multirow[t]{6}{*}{ Low Intensity } & Work Time & $1^{\circ}$ & $1^{\circ}$ \\
\hline & & $(0)$ & $(0)$ \\
\hline & Overwork & $.643^{\star \star \star}$ & $.647^{\star \star \star}$ \\
\hline & & $(.028)$ & $(.028)$ \\
\hline & Too Few Workers & $.640^{\star \star \star}$ & $.642^{\star \star \star}$ \\
\hline & & $(.028)$ & $(.028)$ \\
\hline \multirow[t]{8}{*}{ Safe Working Conditions } & Safety Priority & $1^{\circ}$ & $1^{\circ}$ \\
\hline & & $(0)$ & $(0)$ \\
\hline & Safety Shortcuts & $.971^{\star \star \star}$ & $.970^{\star \star *}$ \\
\hline & & $(.006)$ & $(.006)$ \\
\hline & Safety Teamwork & $1.056^{\star \star \star}$ & $1.057^{\star \star \star}$ \\
\hline & & $(.005)$ & $(.005)$ \\
\hline & Safe Conditions & $.977^{\star \star \star}$ & $.978^{\star \star \star}$ \\
\hline & & $(.006)$ & $(.006)$ \\
\hline \multirow[t]{4}{*}{ Social Life } & Socialize with Relative & & $1^{\circ}$ \\
\hline & & & (0) \\
\hline & Socialize with Neighbor & & $1.170^{\star \star \star}$ \\
\hline & & & $(0.120)$ \\
\hline
\end{tabular}


Standard errors in parentheses

*** $p<0.001,{ }^{* \star} p<0.01,{ }^{*} p<0.05$

${ }^{\circ}$ Constrained to 1

I present the fit statistics for each latent variable model in Table A2. Fit statistics represent whether the proposed model reflects the proposed covariance structure of the structural equation model. Analysts consider a model "strong" if the CFI and TLI are greater than 0.95, and the RMSEA is less than 0.05. Analysts usually consider a model "adequate" if the CFI and TLI are greater than 0.90 and the RMSEA is less than 0.1. Models that have a CFI and TLI less than 0.90 or an RMSEA greater than 0.10 are considered inadequate and, the analyst should consider revising these models.

In this study, the models that only include latent variables are all considered "strong." Meanwhile, the models that include observed covariates are generally considered "adequate," although the RMSEA suggest that Model 2 and 3 are relatively strong.

Table A2. Fit Statistics for Confirmatory Factor Analyses

\begin{tabular}{lcccccc}
\hline \multicolumn{1}{c}{ Model } & \multicolumn{7}{c}{$\begin{array}{c}\text { P-Value } \\
\left(\chi^{2}\right)\end{array}$} & TLI & CFI & RMSEA \\
\hline Job Quality & 627.758 & 67 & 0 & 0.989 & 0.992 & 0.036 \\
All Latent Variable Confirmatory Factor & 707.830 & 131 & 0 & 0.990 & 0.993 & 0.023 \\
Analysis & & & & & & \\
Model 1 (Without Additional Covariates) & 672.477 & 89 & 0 & 0.989 & 0.992 & 0.028 \\
Model 2 (With Additional Covariates) & 4317.919 & 269 & 0 & 0.940 & 0.948 & 0.043 \\
Model 3 (With Additional Covariates and & 6428.868 & 434 & 0 & 0.918 & 0.928 & 0.040 \\
Mediators) & & & & & & \\
\end{tabular}


Table 1. Description of Job Quality Indicator Variables

\begin{tabular}{|c|c|c|c|}
\hline Latent Variable & Indicator & $\begin{array}{l}\text { Variable Text/ } \\
\text { Description }\end{array}$ & Variable Notes \\
\hline \multirow[t]{2}{*}{$\begin{array}{l}\text { Individual Task } \\
\text { Discretion }\end{array}$} & Work Freedom & $\begin{array}{l}\text { "...I am given a lot of freedom to decide how to do } \\
\text { my own work." }\end{array}$ & Reversed \\
\hline & Lot of Say at Work & $\begin{array}{l}\text { "...I have a lot of say about what happens on my } \\
\text { job." }\end{array}$ & Reversed \\
\hline \multirow{2}{*}{$\begin{array}{l}\text { Monetary } \\
\text { Compensation }\end{array}$} & Logged Income & Log-value of Inflation-Adjusted Personal Income & Log of conrinc \\
\hline & Paid by Salary & $\begin{array}{l}\text { Constructed variable: " } 1 \text { " means that a person is } \\
\text { paid a salary rather than hourly or based upon } \\
\text { performance }\end{array}$ & From waypaid \\
\hline \multirow[t]{3}{*}{ Job Security } & Job Security Okay & $\begin{array}{l}\text { "Now I'm going to read you another list of } \\
\text { statements about your main job you do: The Job } \\
\text { Security is Good" }\end{array}$ & Reversed \\
\hline & $\begin{array}{l}\text { Lose Job in Next } 12 \\
\text { Months }\end{array}$ & $\begin{array}{l}\text { "Thinking about the next } 12 \text { months, how likely do } \\
\text { you think it is that you will lose your job or be laid } \\
\text { off-very likely, fairly likely, not too likely, or not at } \\
\text { all likely?" }\end{array}$ & \\
\hline & $\begin{array}{l}\text { Lost Job in Last } 12 \\
\text { Months }\end{array}$ & $\begin{array}{l}\text { "Were you laid off your main job at any time in the } \\
\text { last year?" "1" means a person was not laid off } \\
\text { within the past year; "0" means a person was laid } \\
\text { off within the past year. }\end{array}$ & Reversed \\
\hline \multirow[t]{2}{*}{ Not Intense } & Work Time & "I have enough time to get the job done." & Reversed \\
\hline & $\begin{array}{l}\text { Overwork } \\
\text { Too Few Workers }\end{array}$ & $\begin{array}{l}\text { "I have too much work to do everything well." } \\
\text { "How often are there not enough people or staff to } \\
\text { get all the work done?" }\end{array}$ & \\
\hline \multirow[t]{4}{*}{$\begin{array}{l}\text { Safe Working } \\
\text { Conditions }\end{array}$} & Safety Priority & $\begin{array}{l}\text { "The safety of workers is a high priority with } \\
\text { management where I work." }\end{array}$ & Reversed \\
\hline & Safety Shortcuts & $\begin{array}{l}\text { "There are no significant compromises or shortcuts } \\
\text { taken when worker safety is at stake." }\end{array}$ & Reversed \\
\hline & Safety Teamwork & $\begin{array}{l}\text { "Where I work, employees and management work } \\
\text { together to ensure the safest possible working } \\
\text { conditions." }\end{array}$ & Reversed \\
\hline & Safe Conditions & $\begin{array}{l}\text { "The safety and health conditions where I work are } \\
\text { good." }\end{array}$ & Reversed \\
\hline
\end{tabular}


Table 2. Description of Subjective Well-Being Variables and Mediators

\begin{tabular}{|c|c|c|c|}
\hline & Variable & Variable Text & Recoded Responses \\
\hline \multirow[t]{2}{*}{$\begin{array}{l}\text { Subjective } \\
\text { Well-Being }\end{array}$} & Happiness & $\begin{array}{l}\text { "Taken all together, how would you } \\
\text { say things are these days--would you } \\
\text { say that you are very happy, pretty } \\
\text { happy, or not too happy?" }\end{array}$ & $\begin{array}{l}\text { 1=not too happy; } \\
\text { 2=pretty happy; } \\
\text { 3=very happy }\end{array}$ \\
\hline & $\begin{array}{l}\text { Life is } \\
\text { Exciting }\end{array}$ & $\begin{array}{l}\text { "In general, do you find life exciting, } \\
\text { pretty routine, or dull?" }\end{array}$ & $\begin{array}{l}1=\text { dull; } 2 \text { = routine; } \\
3=\text { exciting }\end{array}$ \\
\hline \multirow[t]{3}{*}{ Social Life } & $\begin{array}{l}\text { Socialize with } \\
\text { Neighbor }\end{array}$ & $\begin{array}{l}\text { [How often do you] Spend a social } \\
\text { evening with someone who lives in } \\
\text { your neighborhood? }\end{array}$ & $\begin{array}{l}\text { 1=never; } \\
2=\text { once a year; } \\
3=\text { several times a year; }\end{array}$ \\
\hline & $\begin{array}{l}\text { Socialize with } \\
\text { Friend }\end{array}$ & $\begin{array}{l}\text { [How often do you] Spend a social } \\
\text { evening with friends who live outside } \\
\text { the neighborhood? }\end{array}$ & $\begin{array}{l}\text { 4=once a month; } \\
5=\text { several times a month; } \\
6=\text { several times a week; } \\
7=\text { =almost daily }\end{array}$ \\
\hline & $\begin{array}{l}\text { Socialize with } \\
\text { Relatives }\end{array}$ & $\begin{array}{l}\text { [How often do you] Spend a social } \\
\text { evening with relatives? }\end{array}$ & \\
\hline $\begin{array}{l}\text { Physical } \\
\text { Health }\end{array}$ & $\begin{array}{l}\text { Poor } \\
\text { Physical } \\
\text { Health }\end{array}$ & $\begin{array}{l}\text {...for how many days during the past } \\
30 \text { days was your physical health not } \\
\text { good? }\end{array}$ & $\begin{array}{l}\text { Number of poor physical } \\
\text { health days between } 0 \\
\text { and } 30\end{array}$ \\
\hline Free Time & $\begin{array}{l}\text { Hours to } \\
\text { Relax }\end{array}$ & $\begin{array}{l}\text { After an average work day, about } \\
\text { how many hours do you have to relax } \\
\text { or pursue activities that you enjoy? }\end{array}$ & $\begin{array}{l}\text { Number of hours to relax } \\
\text { between } 0 \text { and } 24\end{array}$ \\
\hline $\begin{array}{l}\text { Subjective } \\
\text { Class } \\
\text { Identification }\end{array}$ & $\begin{array}{l}\text { Subjective } \\
\text { Class } \\
\text { Identification }\end{array}$ & $\begin{array}{l}\text { If you were asked to use one of four } \\
\text { names for your social class, which } \\
\text { would you say you belong in: the } \\
\text { lower class, the working class, the } \\
\text { middle class, or the upper class? }\end{array}$ & $\begin{array}{l}1=\text { lower class } \\
2=\text { working class } \\
3 \text { = middle class; } \\
4=\text { upper class }\end{array}$ \\
\hline
\end{tabular}


Table 3. Descriptive Statistics for Job Quality, Subjective Well-Being, and Mediators

\begin{tabular}{lccc}
\hline \multicolumn{1}{c}{ Indicator } & Level of Measurement & $\bar{x}$ & sd \\
\hline Work Freedom & Ordinal & 3.39 & 0.82 \\
Lot of Say at Work & Ordinal & 2.95 & 0.88 \\
Logged Income & Continuous & 9.98 & 1.14 \\
Paid by Salary & Dichotomous & 0.35 & 0.48 \\
Job Security Okay & Ordinal & 3.31 & 0.88 \\
Lose Job in Next 12 Months & Ordinal & 3.41 & 0.85 \\
Lost Job in Last 12 Months & Dichotomous & 0.92 & 0.27 \\
Work Time & Ordinal & 3.2 & 0.85 \\
Overwork & Ordinal & 2.76 & 0.73 \\
Too Few Workers & Ordinal & 2.26 & 0.98 \\
Safety Priority & Ordinal & 3.32 & 0.69 \\
Safety Shortcuts & Ordinal & 3.29 & 0.71 \\
Safety Teamwork & Ordinal & 3.25 & 0.68 \\
Safe Conditions & Ordinal & 3.29 & 0.63 \\
Happiness & Ordinal & 2.16 & 0.64 \\
Life is Exciting & Ordinal & 2.46 & 0.59 \\
Physical Health & Continuous & 2.62 & 6.17 \\
Socialize with Relative & Ordinal & 4.64 & 1.63 \\
Socialize with Neighbor & Ordinal & 3.42 & 2.04 \\
Socialize with Friend & Ordinal & 4.12 & 1.61 \\
Subjective Class ID & Ordinal & 2.44 & 0.67 \\
Hours to Relax & Continuous & 3.73 & 2.75 \\
& & & \\
\hline
\end{tabular}


Table 4. Impact of Job Quality on Subjective Well-Being

\begin{tabular}{|c|c|c|c|c|}
\hline Dependent Variable & Independent Variable & Model 1 & Model 2 & Model 3 \\
\hline \multirow[t]{16}{*}{ Subjective Well-Being } & Individual Task Discretion & $\begin{array}{l}.125^{\star \star} \\
(.047)\end{array}$ & $\begin{array}{l}.135^{\star \star} \\
(.047)\end{array}$ & $\begin{array}{c}.079 \\
(.049)\end{array}$ \\
\hline & Monetary Compensation & $\begin{array}{l}.198^{\star \star \star} \\
(.041)\end{array}$ & $\begin{array}{l}.168^{\star *} \\
(.057)\end{array}$ & $\begin{array}{l}.126^{\star} \\
(.061)\end{array}$ \\
\hline & Job Security & $\begin{array}{l}.153^{\star \star \star} \\
(.032)\end{array}$ & $\begin{array}{l}.125^{\star \star \star} \\
(.031)\end{array}$ & $\begin{array}{l}.122^{\star \star \star} \\
(.032)\end{array}$ \\
\hline & Low Intensity & $\begin{array}{l}.117^{\star \star} \\
(.035)\end{array}$ & $\begin{array}{l}.119 \star \star \\
(.035)\end{array}$ & $\begin{array}{l}.084^{\star} \\
(.037)\end{array}$ \\
\hline & Safe Working Conditions & $\begin{array}{l}.098^{\star \star \star} \\
(.027)\end{array}$ & $\begin{array}{l}.096^{\star *} \\
(.029)\end{array}$ & $\begin{array}{l}.091^{\star *} \\
(.028)\end{array}$ \\
\hline & Social Life & & & $\begin{array}{l}.395^{\star \star \star} \\
(.075)\end{array}$ \\
\hline & Subjective Class ID & & & $\begin{array}{l}.129 * \star \star \\
(.026)\end{array}$ \\
\hline & Poor Physical Health & & & $\begin{array}{c}-.01^{\star \star \star} \\
(.003)\end{array}$ \\
\hline & Hours to Relax & & & $\begin{array}{l}.022^{\star \star} \\
(.007)\end{array}$ \\
\hline & Black & & $\begin{array}{c}-.065 \\
(.04)\end{array}$ & $\begin{array}{c}-.064 \\
(.04)\end{array}$ \\
\hline & Latino & & $\begin{array}{l}-.087^{*} \\
(.044)\end{array}$ & $\begin{array}{l}-.084 \\
(.044)\end{array}$ \\
\hline & Other Race & & $\begin{array}{l}-.128 \\
(.073)\end{array}$ & $\begin{array}{l}-.126 \\
(.072)\end{array}$ \\
\hline & Female & & $\begin{array}{l}-.036 \\
(.027)\end{array}$ & $\begin{array}{l}-.036 \\
(.027)\end{array}$ \\
\hline & Age & & $\begin{array}{c}-.174^{\star \star \star} \\
(.044)\end{array}$ & $\begin{array}{c}-.171^{\star \star \star} \\
(.044)\end{array}$ \\
\hline & Age Sq. & & $\begin{array}{c}.002^{\star \star \star} \\
(0)\end{array}$ & $\begin{array}{c}.002^{\star \star \star} \\
(0)\end{array}$ \\
\hline & Education & & $\begin{array}{l}.049^{\star \star \star} \\
(.004)\end{array}$ & $\begin{array}{l}.049^{\star \star \star} \\
(.004)\end{array}$ \\
\hline
\end{tabular}




\begin{tabular}{|c|c|c|c|}
\hline & Married & $\begin{array}{l}.459 * \star \star \\
(.029)\end{array}$ & $\begin{array}{l}.429^{\star \star \star} \\
(.028)\end{array}$ \\
\hline & Has Kids & $\begin{array}{c}-.119 \star \star \star \\
(.032)\end{array}$ & $\begin{array}{c}-.116^{\star \star \star} \\
(.03)\end{array}$ \\
\hline & Attended Relig. Services & $\begin{array}{l}.044^{\star * \star} \\
(.005)\end{array}$ & $\begin{array}{l}.043^{\star \star \star} \\
(.005)\end{array}$ \\
\hline & Year: 2006 & $\begin{array}{c}.02 \\
(.032)\end{array}$ & $\begin{array}{l}.025 \\
(.031)\end{array}$ \\
\hline & Year: 2010 & $\begin{array}{l}-.086^{\star} \\
(.035)\end{array}$ & $\begin{array}{l}-.079^{\star} \\
(.033)\end{array}$ \\
\hline \multirow[t]{3}{*}{ Social Life } & Individual Task Discretion & & $\begin{array}{l}.118^{\star \star \star} \\
(.032)\end{array}$ \\
\hline & Monetary Compensation & & $\begin{array}{l}-.018 \\
(.033)\end{array}$ \\
\hline & Low Intensity & & $\begin{array}{c}.038 \\
(.024)\end{array}$ \\
\hline \multirow[t]{4}{*}{ Physical Health } & Monetary Compensation & & $\begin{array}{c}-1.52^{\star \star \star} \\
(.278)\end{array}$ \\
\hline & Job Security & & $\begin{array}{c}.053 \\
(.149)\end{array}$ \\
\hline & Low Intensity & & $\begin{array}{c}-.92^{\star \star \star} \\
(.16)\end{array}$ \\
\hline & Safe Working Conditions & & $\begin{array}{l}-.244 \\
(.124)\end{array}$ \\
\hline \multirow[t]{3}{*}{ Subjective Class ID } & Individual Task Discretion & & $\begin{array}{l}.104^{\star \star \star} \\
(.023)\end{array}$ \\
\hline & Monetary Compensation & & $\begin{array}{l}.301^{\star \star \star} \\
(.032)\end{array}$ \\
\hline & Low Intensity & & $\begin{array}{l}.044^{\star} \\
(.018)\end{array}$ \\
\hline Hours to Relax & Low Intensity & & $\begin{array}{l}.528^{\star \star \star} \\
(.054)\end{array}$ \\
\hline
\end{tabular}


Table 5. Effect of of Job Quality on Subjective Well-Being (Standardized Coefficients)

\begin{tabular}{lccc}
\hline Independent Variable & Model 1 & Model 2 & Model 3 \\
\hline Individual Task Discretion & $.139^{\star \star}$ & $.129^{\star \star}$ & .076 \\
Monetary Compensation & $.235^{\star \star \star}$ & $.127^{\star \star}$ & $.097^{\star}$ \\
Job Security & $.201^{\star \star \star}$ & $.149^{\star \star \star}$ & $.145^{\star \star \star}$ \\
Low Intensity & $.150^{\star \star}$ & $.134^{\star \star}$ & $.095^{\star}$ \\
Safe Working Conditions & $.131^{\star \star \star}$ & $.110^{\star \star}$ & $.106^{\star \star}$ \\
& & & \\
\hline
\end{tabular}


Table 6. How Job Quality Affects Subjective Well-Being

\begin{tabular}{lccccc}
\hline Job Quality Dimension & Direct Effect & Via Social Life & Via Physical Health & Via Class ID & Via Hours to Relax \\
\hline Individual Task Discretion & n.s. & $\mathrm{P}<0.001$ & & $\mathrm{P}<0.001$ & \\
Monetary Compensation & $\mathrm{P}<0.05$ & n.s. & $\mathrm{P}<0.001$ & $\mathrm{P}<0.001$ & \\
Job Security & $\mathrm{P}<0.001$ & & n.s. & & $\mathrm{P}<0.05$ \\
Low Intensity & $\mathrm{P}<0.05$ & n.s. & $\mathrm{P}<0.001$ & $\mathrm{P}<0.001$ \\
Safe Working Conditions & $\mathrm{P}<0.01$ & & n.s. & & \\
\hline
\end{tabular}


Table 7. Effect Sizes of Indirect Effects of Job Quality on Subjective Well-Being (Standardized Coefficients)

\begin{tabular}{llc}
\hline Job Quality Dimension & \multicolumn{1}{c}{ Mediator } & Indirect Effect \\
\hline Individual Task Discretion & Social Life & $0.46^{\star \star}$ \\
& & $(0.014)$ \\
Individual Task Discretion & Subjective Class ID & $0.013^{\star \star \star}$ \\
& & $(0.004)$ \\
Monetary Compensation & Physical Health & $0.012^{\star \star}$ \\
Monetary Compensation & Subjective Class ID & $(0.004)$ \\
& & $0.030^{\star \star \star}$ \\
Low Work Intensity & Physical Health & $0.006)$ \\
Low Work Intensity & Subjective Class ID & $0.011^{\star \star}$ \\
& & $0.003)$ \\
Low Work Intensity & Hours to Relax & $\left(0.006^{\star}\right.$ \\
& & $0.013^{\star \star}$ \\
& & $(0.004)$ \\
\hline
\end{tabular}


Figure 1. The Impact of Job Quality on Subjective Well-Being, No Control Variables $\underline{\text { (Model 1) }}$

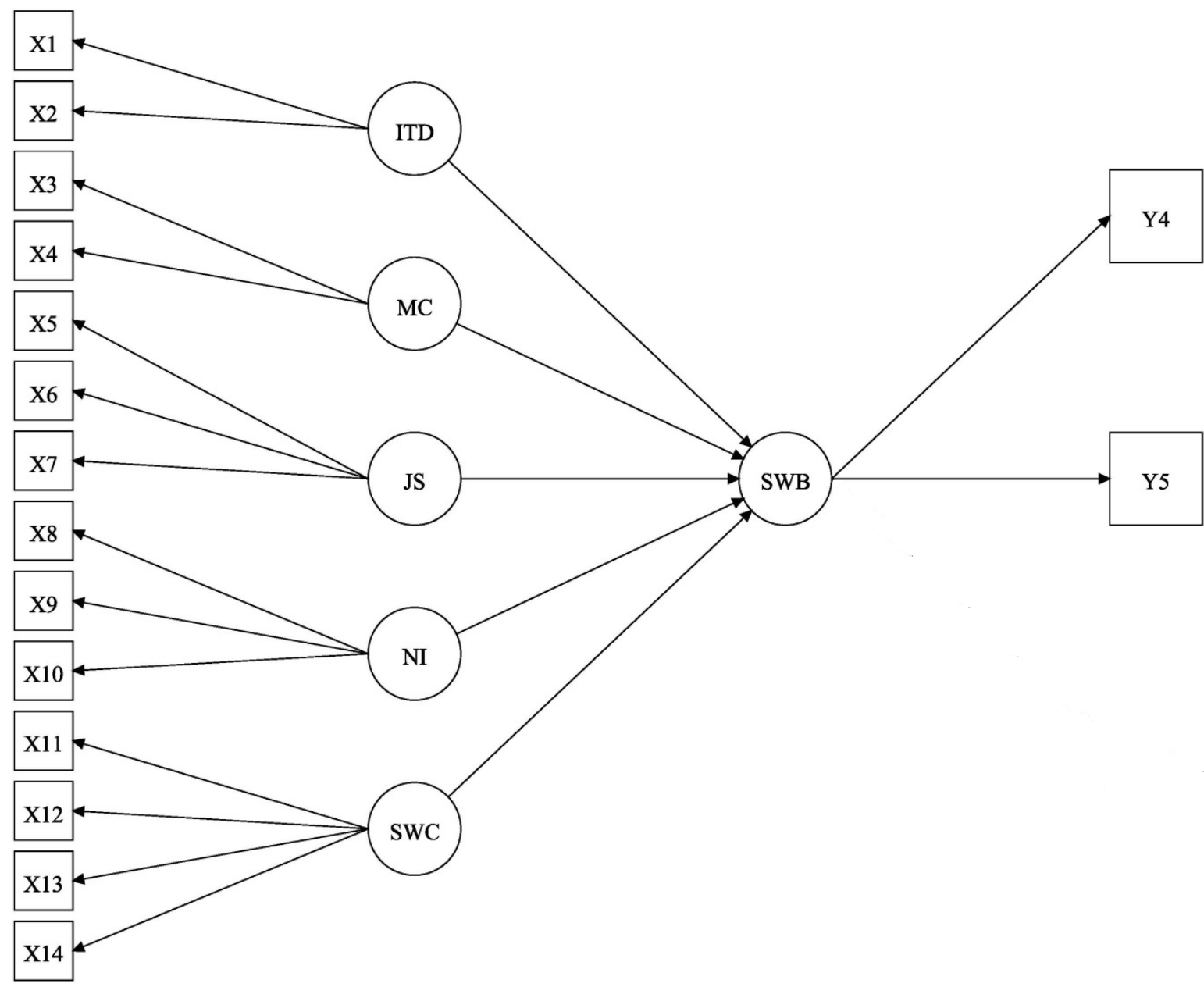

Factor Structure:

X1: Work Freedom

X2: Lot of Say

X3: Logged Income

X4: Paid by Salary

X5: Job Security Okay

X6: Lose Job in Next 12 Months

X7: Lost Job in Last 12 Months

X8: Work Time

X9: Overwork

X10: Too Few Workers

X11: Safety Priority

X12: Safety Shortcuts

X13: Safety Teamwork

X14: Safe Conditions
Latent Variables:

Y4: Happiness

Y5: Excitement for Life

ITD: Individual Task Discretion

MC: Monetary Compensation

JS: Job Security

NI: Not Intense

SWC: Safe Working Conditions

SOC: Social Life

SWB: Subjective Well-Being 
Figure 2. The Impact of Job Quality on Subjective Well-Being, With Additional Covariates (Model 2)

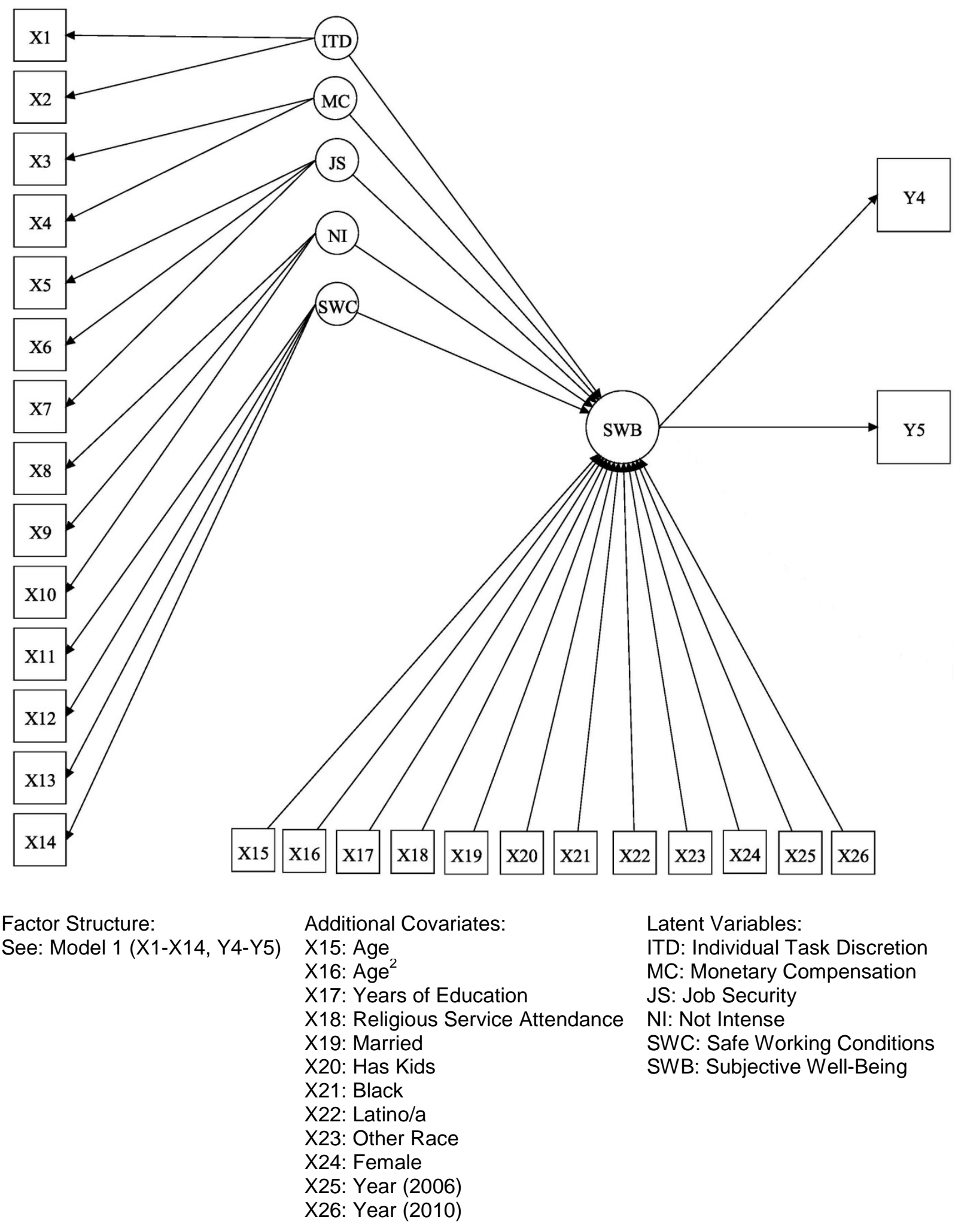


Figure 3. The Impact of Job Quality on Subjective Well-Being, With Mediators and Additional Covariates (Model 3)

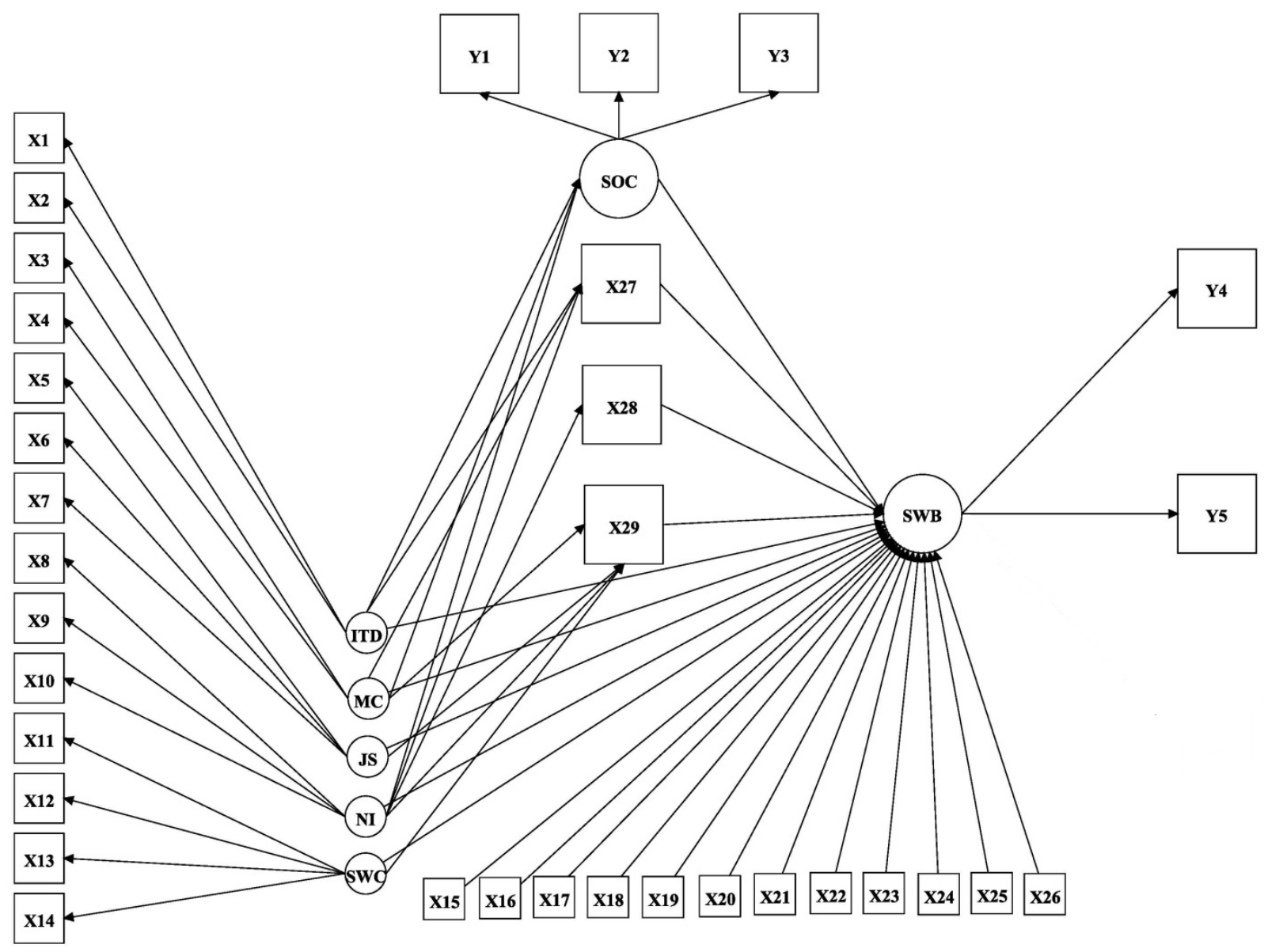

Factor Structure:

See: Model 1 (X1-X14, Y4-Y5)

Y1: Socialize with Neighbor

Y2: Socialize with Friends

Y3: Socialize with Relative

Mediators

X27: Subjective Class ID

X28: Hours to Relax

X29: Physical Health
Additional Covariates:

X15: Age

$\mathrm{X} 16: \mathrm{Age}^{2}$

X17: Years of Education

X18: Religious Service Attendance X19: Married

X20: Has Kids

$\mathrm{X} 21$ : Black

X22: Latino/a

X23: Other Race

X24: Female

X25: Year (2006)

X26: Year (2010)
Latent Variables:

ITD: Individual Task Discretion MC: Monetary Compensation JS: Job Security

NI: Not Intense

SWC: Safe Working Conditions

SOC: Social Life

SWB: Subjective Well-Being 